\title{
nombalina
}

(8)

Diógenes Laércio e os Topoi da tradição biográfica: considerações sobre o livro VII

Autor(es): $\quad$ Brandão, José Luís Lopes

Publicado por: Imprensa da Universidade de Coimbra

URL

persistente:

URI:http://hdl.handle.net/10316.2/34714

DOI: $\quad$ DOI:http://dx.doi.org/10.14195/978-989-721-042-6_14

Accessed : $\quad$ 26-Apr-2023 11:31:09

A navegação consulta e descarregamento dos títulos inseridos nas Bibliotecas Digitais UC Digitalis, UC Pombalina e UC Impactum, pressupõem a aceitação plena e sem reservas dos Termos e Condições de Uso destas Bibliotecas Digitais, disponíveis em https://digitalis.uc.pt/pt-pt/termos.

Conforme exposto nos referidos Termos e Condições de Uso, o descarregamento de títulos de acesso restrito requer uma licença válida de autorização devendo o utilizador aceder ao(s) documento(s) a partir de um endereço de IP da instituição detentora da supramencionada licença.

Ao utilizador é apenas permitido o descarregamento para uso pessoal, pelo que o emprego do(s) título(s) descarregado(s) para outro fim, designadamente comercial, carece de autorização do respetivo autor ou editor da obra.

Na medida em que todas as obras da UC Digitalis se encontram protegidas pelo Código do Direito de Autor e Direitos Conexos e demais legislação aplicável, toda a cópia, parcial ou total, deste documento, nos casos em que é legalmente admitida, deverá conter ou fazer-se acompanhar por este aviso. 


\section{Dos Homens e suas Ideias \\ Estudos sobre as Vidas de Diógenes Laércio}

Delfim Leão, Gabriele Cornelli \& Miriam C. Peixoto (coords.) 


\title{
Diógenes LAÉRCIO E OS TOPOI DA TRADIÇÃo BIOGRÁFICA: CONSIDERAÇÕES SOBRE O LIVRO VII (Diogenes Laertius and the topoi of the biographical tradition: remarks about the Book VII)
}

\author{
José Luís Lopes BRANDÃo \\ Universidade de Coimbra
}

\begin{abstract}
Resumo: $\mathrm{O}$ presente estudo pretende facultar uma abordagem introdutória à Vidas e Teorias dos Filósofos Ilustres, pondo em evidência o carácter biográfico da obra, inserindo o autor na história da biografia e proporcionando concomitantemente uma exposição sobre as fases do desenvolvimento do género no mundo greco-romano. Além disso, salientam-se as implicações que a escolha de tal género acarretam no que toca às Vidas dos filósofos, focalizando no livro VII a análise e ilustração dos principais tópicos biográficos.
\end{abstract}

Palavras-chave: Diógenes Laércio, Biografia, Vidas de Filósofos

Aвstract: This article aims to provide an introduction to the Lives of Eminent Philosophers of Diogenes Laertius, stressing the biographical target of the author's task, inserting him in the history of biography, and providing concurrently an explanation about the genre in the Greek and Roman world. Moreover, the article stresses the effects of the genre in the composition of philosopher's lives, taking the Book VII as a case study to illustrate the main biographical topics.

KEY-words: Diogenes Laertius, Biography, Lives of Philosophers

Ao ler Diógenes Laércio podemos sentir-nos por vezes desapontados se vamos à espera de encontrar um manual de filosofia. Mas temos de ter em conta que se trata antes de mais de um biógrafo que, como muitos outros, relata as Vidas de grandes homens do passado. Há indicações no texto de que está mais interessado nos filósofos e nas suas vidas do que na sua filosofia. No caso de Zenão de Cítio, justifica mesmo a exposição da filosofia com o facto de se tratar do fundador da escola:

Pareceu-me bem tratar de modo geral as doutrinas ( $\delta$ ó $\mu \alpha \alpha \alpha)$ de todos os estóicos na Vida de Zenão devido ao facto de ele ser o fundador da escola (aîpeбıৎ). Foi já apresentada a copiosa lista dos seus livros, nos quais ele falou como nenhum outro estóico. As doutrinas ( $\delta o ́ \gamma \mu \alpha \tau \alpha)$ são em geral as seguintes. Serão, contudo, expostas em síntese ( outros casos. (7.38)

Diógenes Laércio escreve biografia, o que tem diversas implicações: relata a vida do nascimento à morte - uma das definições de biografia - e não só o tempo de cultivo da filosofia; está preocupado com o carácter dos biografados; 
inclui pormenores anedóticos e de erudição, mas que nada acrescentam à filosofia; integra-se numa longa tradição, grega e romana; segue os métodos e as rubricas tradicionais do género biográfico.

Uma das principais características da biografia antiga, tanto de homens de letras como de políticos, é que estava muito preocupada com o carácter, ilustrado através de anedotas e ditos dos próprios: basta lembrar o prefácio ao Alexandre de Plutarco:

O que eu estou a escrever não são Histórias, mas Vidas; e nem sempre é nos feitos mais notáveis que se verifica a manifestação de virtude ou de vício. Mas, muitas vezes, um pequeno acto, seja um dito, seja um gracejo, contribui mais para a revelação do carácter do que batalhas com dezenas de milhares de mortos ou as maiores manobras militares e assédios de cidades.

Mutatis mutandis, no que toca aos filósofos, Diógenes parece dar mais importância ao carácter do que aos ensinamentos. São várias as referências ao carácter de Zenão, por exemplo. Mesmo quando se detém sobre os escritos dos filósofos é frequentemente porque tal revela o carácter, como no caso de Crisipo (7.180) em que o número de obras justifica a sua diligência; mas também a arrogância, pois entre tantos livros não dedicou nenhum a reis (7.185). O carácter, as virtudes e os vícios são ilustrados com exempla - para o que seria necessário recorrer a uma série de anedotas e ditos célebres que já circulavam em selectas. A análise do carácter sobrepõe-se à exposição cronológica e até à coerência interna; as frequentes contradições, oriundas acaso de fontes diferentes, não preocupam geralmente os biógrafos. Zenão é verdadeiro e digno (7.28), mas também de carácter amargo (7.16); a sua beatitude destacase no contexto da morte (7.28). A capacidade de Cleantes em suportar afrontas dos colegas, que lhe chamam burro (7.171), e de um poeta no teatro (1.173) vale-lhe a associação a Hércules, pela sua resistência. E a sua modéstia leva-o a dizer que prefere censurar-se a si próprio (7.171).

Porque não se trata de encómio, de que falaremos adiante, os vícios aparecem na biografia a contrabalançar as virtudes. Avaritia, luxuria, libido são os mais frequentes. Diz-se que Dionísio de Heracleia cedia a os prazeres sem o dissimular, adoptando uma vida "mole" (7.167). Tradições hostis podem estar na base da afirmação de que Crisipo defendia na sua República o incesto e que se comesse a carne dos mortos (7.188), mas não se diz o contexto. A origem pode estar nos sofismas que ele produzia e que levavam a extremos, a jogos de palavras com resultados monstruosos. Tal imagem de Crisipo pode mesmo porvir de distorções da comédia, como aconteceu com Sócrates ${ }^{1}$. A

\footnotetext{
${ }^{1}$ Vide Grau i Guijarro 2009 277-278.
} 
atribuição do vício da avareza a Zenão, em contraste com o seu ascetismo (7.13 e 16-17), denota provavelmente a presença de uma fonte hostil e de um topos frequente na comédia. Louva-se a pobreza de Cleantes (1.168), bem como a sua dedicação ao trabalho, que fez com que fosse escolhido como sucessor de Zenão (7.174), e o facto de preferir a sua vida à dos ricos ${ }^{2}$.

Diógenes integra-se, portanto, numa longa tradição cujo desenvolvimento muito devia à pesquisa filosófica, em especial à escola peripatética. Mas, com o pouco que nos resta da biografia antiga (dois encómios do século IV, Evágoras e Agesilau, de Isócrates e Xenofonte respectivamente, uma parte substancial da Vida de Eurípides de Sátiro, descoberta há um século, Cornélio Nepos e essencialmente a biografia imperial: Plutarco, Suetónio, Diógenes Laércio, Filóstrato, Historia Augusta) o nosso conhecimento depende muito de fragmentos e notícias indirectas e está sujeito às conjecturas dos estudiosos modernos $^{3}$.

Entre os precursores da biografia grega em prosa, podem contar-se a saga heróica e as formas líricas que se concentram no tratamento de uma personalidade, como hinos, ditirambos, cantos fúnebres, encómios, epinícios, elegias. Discursos e cantos fúnebres são virtuais biografias e existiriam certamente na Grécia (Cic. Leg. 2.63). Os Gregos interessavam-se também pelos relatos sobre heróis e semideuses (Teócrito, Ep. 2.2), pelo que no início do século $\mathrm{V}$ começam a substituir o verso pela prosa neste tipo de biografia mitológica, e sentem curiosidade por poetas do passado 4 .

Em meados do século $V$, os escritos biográficos aparecem na região da Iónia, pela mesma altura em que surgem os primeiros livros de geografia, genealogia e história política. Cílax de Carianda, além de escrever, com um cunho autobiográfico, sobre explorações geográficas ${ }^{5}$, compôs, segundo a Suda, por volta de 480, uma biografia de Heraclides, tirano de Mílasa (guerreiro referido em Heródoto, 5.121) ${ }^{6}$. A seguir, aparece o poeta Íon de Quios, que escreve (por volta de 440), na primeira pessoa, sobre personalidades que conheceu (como Címon, Péricles, Ésquilo e Sófocles) e

\footnotetext{
${ }^{2}$ Uma tradição hostil, presente em Filodemo (19) e Quintiliano (Inst.12.7.9), parece sugerir avareza, ao dizer que Cleantes exigia um pagamento antecipado.

${ }^{3}$ Vide Momigliano 1993 9-10.

${ }^{4}$ Como Homero e Hesíodo. Inventa-se um agon entre os dois. Há grande interesse pela tradição dos Sete Sábios, pelas as canções de banquete, pela vida de Esopo, pelas lendas relacionadas com Arquíloco, como o seu encontro com as musas, modelado pelos admiradores a partir de Hesíodo. Vide Momigliano 1993 24-28.

${ }^{5}$ Explorou as costas da Índia sob as ordens de Dario I e escreveu um relatório que dedicou ao próprio Dario. Cf. Heródoto 4.44; Aristóteles, Pol. 7.1332b24. Vide Austin 1990299.

${ }^{6}$ Pela mesma altura, um historiador e geógrafo jónio, Hecateu de Mileto, apresenta, de igual modo, relatos na primeira pessoa e escreve genealogias orientais, que incluem origem divina de certas famílias.
} 
não negligencia curiosidades que farão as delícias da biografia: nos fragmentos de Epidemiai ('visitas'), Íon manifesta interesse por contemporâneos ilustres, pelo pormenor anedótico e realista, e chega mesmo a inserir traços físicos ${ }^{7}$. Também o prosador Estesímbroto, natural de Tasos, no Egeu, se interessa por figuras dominantes da vida pública ateniense do tempo: no seu panfleto (de que sobrevivem extensos fragmentos) sobre Temístocles, Tucídides, filho de Milésias, e Péricles, refere costumes pessoais, pormenores anedóticos, explora o sensacional, faz citações directas e mistura vida privada com vida pública. Além disso, inclui nos seus trabalhos registos biográficos de poetas do passado ${ }^{8}$. Xanto da Lídia, contemporâneo de Heródoto, autor de uma História da Lídia, poderá ser também autor de uma biografia de Empédocles, segundo se deduz de Diógenes Laércio (8.63), mas há dúvidas. Segundo Momigliano, o facto de o interesse por pormenores biográficos ser mais evidente na Ásia Menor e na cultura Jónia (numa altura em que a região era governada por reis Persas e tiranos locais $)^{9}$ deve-se à influência persa, em cujo território a autobiografia estava na $\operatorname{moda}^{10}$, e ao modelo dos contos orientais ${ }^{11}$. Em suma, parece que biografia e autobiografia não aparecem mais cedo ou mais tarde que a história política, mas se desenvolvem paralelamente ${ }^{12}$. Contudo, o carácter residual da biografia que nos chegou do séc. V, em comparação com a obra histórica de Heródoto e Tucídides, não nos permite ter grandes certezas.

Stuart (1928 44-55) aponta razões religiosas e cívicas para a resistência dos Gregos nesta fase à biografia dos políticos: a ideia da exaltação do estado prevalece sobre o indivíduo. Neste ambiente, floresce a história, de que são testemunho as obras de Heródoto e Tucídides. Mas esta supremacia do colectivo sobre o individual tem os dias contados. No século IV, o homem já não é visto tanto como elemento do estado, mas mais como um indivíduo, como denota o realismo da arte de Praxíteles e Lisipo. As escolas de retórica e as escolas filosóficas desenvolvem a arte de falar do indivíduo, seja ele um terceiro,

${ }^{7}$ Como no caso de Címon (frg. 6 Müller, FHG II 46). Vide Stuart 1928 35, 43; Jacoby 1947 1-17.

${ }^{8}$ Momigliano (1993 30) considera que deve ser o predecessor dos escritores de monografias sobre tiranos e demagogos, pelo que o compara ao historiador Teopompo.

${ }^{9}$ Sabe-se mais sobre a vida de reis persas (Ciro, Cambises), de Creso e de gregos ao serviço dos reis persas (como Demócedes) do que sobre figuras da política atenienses da mesma época; vide Momigliano 1993 33-38.

${ }^{10}$ Vide Momigliano 1990 5-16. Este autor lembra que, ao contrário dos Gregos, os Persas, para estabelecerem direitos legais, davam muita importância à citação de documentos.

${ }^{11}$ No mesmo século em que Neemias e talvez Esdras (alguns atribuem-lhe a autoria do livro do mesmo nome) escrevem autobiografias na Judeia, o poeta Íon escreve memórias em Quios. O relatório de Cílax e o Périplo de Hanão serão da mesma época. Vide Momigliano 199333 ss.

${ }^{12}$ Como sugere Momigliano 1993109. 
ou seja o próprio sujeito da enunciação. Os retóricos exploram o encomium; os filósofos, a biografia idealizada de monarcas e filósofos. Mas tanto uns como outros misturam realidade e ficção ${ }^{13}$.

Assim, podemos dizer que, à parte aquelas pálidas tentativas anteriores (pelo menos a Vida de Heraclides de Cílax parece constituir uma primeira experiência), a biografia literária remonta ao séc. IV: o Evágoras de Isócrates (escrito por volta de 370 a.C) e o Agesilau de Xenofonte (c. 360). Não se pode, contudo, dizer que seja biografia propriamente dita, mas mais estrictamente encomium ${ }^{14}$ : não há intenção de fazer obra histórica, mas de elogiar o herói e, através da exposição das suas virtudes, apontá-lo como modelo para os concidadãos. Procura-se esconder os pormenores não dignificantes da figura elogiada ${ }^{15}$. Tanto o Agesilau como o Evágoras se concentram no carácter como algo acabado, que se manifesta desde criança, e pressupõem que os traços da personalidade são iluminados pelas acções. Mas enquanto Isócrates mistura a parte descritiva na narrativa ${ }^{16}$, Xenofonte separa-as ${ }^{17}$.

$\mathrm{O}$ desenvolvimento do género parece ser fortalecido pelo interesse pela figura de Sócrates ${ }^{18}$.É o caso dos Memoráveis (Apomnemoneumata, cuja tradução latina correspondente seria Commentarii): aí encontramos uma compilação das conversas filosóficas de Sócrates a par de referências ao seu aspecto físico, à sua vida frugal e gostos simples e às suas actividades diárias, numa combinação de relatos anedóticos e intenção apologética. Se é verdade que as compilações de ditos célebres de filósofos e sábios já existiam, Xenofonte tornou-se um modelo para a colecção de conversas filosóficas: Zenão, por exemplo, coleccionou Memorabilia de Crates (Diógenes Laércio 7.4). A presença da

13 Vide Stuart 1928 128-129; Momigliano 1993 43-46; 102. Momigliano salienta a descontinuidade em relação ao século $V$ e prefere falar de um novo começo.

${ }^{14}$ Uma "quasi biografia”, nas palavras de Stuart 1928 19. Isócrates considera-se, no prólogo do Evágoras, pioneiro da transposição para prosa do encomium, que era em verso; mas talvez se trate de uma forma de captatio com muitos paralelos na literatura clássica, como nota Stuart 1928 91-118. Xenofonte faz saber que o seu Agesilau é um louvor, não um lamento pela morte do monarca espartano (Ages. 10.3).

${ }^{15}$ Isócrates (9.71) omite o assassínio de Evágoras: diz que ele viveu uma longa vida e escapou às enfermidades. A deficiência física de Agesilau (era coxo) determina a omissão do aspecto físico, enquanto em Evágoras se elogia a beleza e robustez física crescentes (22-23).

${ }^{16}$ Diz também Stuart (1928 57-59; 69) que Isócrates e Xenofonte são herdeiros do modelo retórico de Górgias. Momigliano (1993 49-52) sustenta que Xenofonte tomou como modelo Evágoras, mas que a influência é secundária (p. 52) e que para o arranjo da parte sistemática em virtudes (piedade, justiça, moderação, coragem, sabedoria, patriotismo, urbanidade) segue um esquema que remonta a Górgias, também usado por outros socráticos.

${ }^{17}$ Depois de uma narrativa cronológica inicial dos feitos de Agesilau, em que pontua o discurso com expressões de aprovação (1), Xenofonte passa a uma exposição através de rubricas, encabeçadas por virtudes, sob as quais cataloga o seu material exemplificativo (2-9). Vide Stuart 1928 60-90; Momigliano 1993 49-52; Wallace-Hadrill 198471.

${ }^{18}$ Vide Dihe 1956 13-34; Grau i Guijarro 2009 18-21. 
ficção na biografia é uma tendência desenvolvida igualmente na Ciropedia, uma biografia romanceada (ou uma "paedagogical novel", como diz Momigliano), na qual Xenofonte, em vez de descrever a figura histórica, apresenta Ciro como o produto de uma educação ideal ${ }^{19}$.

A verdade é que também a historiografia da época faz incursões no campo da biografia e autobiografia, se assim a podemos a chamar ${ }^{20}$. Xenofonte inclui na Anábase retratos de generais (um topos recorrente da biografia). Além disso, esta obra configura um modelo autobiográfico ${ }^{21}$, seguido depois por César, por exemplo. Teopompo, nas Filípicas, centradas, como o nome indica, em Filipe da Macedónia, inclui, como se pode ver pelos fragmentos sobreviventes, referências aos vícios e virtudes, digressões sobre pormenores considerados biográficos e um longo excurso sobre thaumasia. Éforo, nas histórias de Alexandre e nos Diádocos, apresenta excertos de historiografia centrada em indivíduos. Políbio (16.7-9) critica Teopompo por incluir relatos inverosímeis e prodígios; e acusa Éforo e Teopompo (juntamente com Timeu) de usarem a imaginação para suprir a falta de conhecimentos militares $(12.25 \mathrm{f}-\mathrm{h})^{22}$, o que mostra que, no século IV, a distinção entre biografia e história não estava definida no conteúdo. Mas, se o cruzamento da fronteira entre realidade e ficção se operava tanto na biografia como na historiografia, esperava-se, contudo, um maior respeito pela veracidade da parte do historiador, segundo a prática consagrada por Heródoto e Tucídides ${ }^{23}$. E, independentemente das interpenetrações, a historiografia centra-se nos acontecimentos políticos e a biografia no indivíduo.

É sobretudo aos peripatéticos que se concede o mérito do aperfeiçoamento da biografia, apesar de Aristóteles não ter cultivado o género. Entre os seguidores desta escola, a biografia tende a reflectir o interesse pela pesquisa histórica e pela filosofia ética, na linha do livro IV da Ética a Nicómaco de Aristóteles e do impulso do estudo dos caracteres por parte Teofrasto. Embora, à excepção de Teofrasto, só nos restem fragmentos, a maior porção dos trabalhos da primeira

${ }^{19}$ Vide Momigliano 1993 53-57. A coroar a vida deste modelo de rei, sobrevém uma da morte serena e sábia, entre considerações sobre a imortalidade alma, contrariamente ao testemunho de Heródoto (1.214) segundo o qual Ciro morreu em combate.

${ }^{20}$ Momigliano (1993 89-93) contesta a opinião de Leo e Wilamowitz de que a autobiografia era desconhecida dos gregos. Temos notícias de que vários monarcas escreveram 'memórias' (bypomnemata).

${ }^{21}$ Outros exemplos de escrito autobiográfico da época são: Antidosis de Isócrates, um discurso de defesa em que analisa a sua vida passada; o De corona de Demóstenes, a sua autodefesa perante as acusações de Ésquines e apologia de uma política anti-macedónica. As Apologias de Sócrates de Xenofonte e Platão são biografias disfarçadas de autobiografias. Mas a Carta 7 de Platão é considerada por Momigliano (1993 58-62) autobiografia, e não biografia da autoria de um discípulo, como outros sugerem.

${ }^{22}$ Vide Ullman 194232.

${ }^{23}$ Vide Momigliano 1993109. 
geração parece ter sido constituído mais por colecções de anedotas e máximas que por biografia propriamente $\operatorname{dita}^{24}$. Mas alguns escreveram mesmo Vidas. Aristóxeno de Tarento (nas palavras de Jerónimo, longe omnium doctissimus), discípulo de Aristóteles da primeira vaga, tem sido considerado, por isso, o criador da chamada biografia peripatética ${ }^{25}$ : escreve Vidas de homens, que incluíam Vidas de Pitágoras, Sócrates e Platão e é fonte de Diógenes Laércio. Mas outros autores dessa geração floresceram. Clearco escreve um encomium de Platão, o que mostra que aquele antigo género continua popular. Dicearco, alarga a noção de bios a uma nação: Vida da Grécia; outro título - Peri bion - faz supor um trabalho sobre diferentes tipos de vida. Fânias, também discípulo de Aristóteles e amigo de Teofrasto, escreveu Vidas não só de poetas e filósofos, mas também de Tiranos da Sicília, com intuitos moralizantes ${ }^{26}$. O seus relatos sobre a morte de homens ilustres antecipam o trabalho de Titínio Capitão, no século I-II d.C.

Quanto ao objecto, de modo diferente dos encomiastas, que se debruçam sobre figuras do seu conhecimento pessoal (ou figuras lendárias, cujo tratamento era apenas retórico), para os peripatéticos são biografáveis tanto figuras de um passado distante como contemporâneos. Além disso, não se faz biografia apenas de políticos e generais, mas de tiranos, artistas, filósofos e poetas. Uma das caraterísticas dos peripatéticos é a prática de agrupar no mesmo livro homens da mesma profissão. Sátiro escreveu, no final do século III, Vidas de monarcas, políticos, oradores, poetas e filósofos, entre as quais uma Vida de Eurípides, descoberta no início do século $\mathrm{XX}^{27}$, curiosamente escrita na forma de diálogo; Hermipo de Esmirna ${ }^{28}$ é autor de um vasto trabalho sobre legisladores arcaicos, os sete sábios, filósofos, poetas; Aristóxeno inclui no seu currículo Vidas de tocadores de flauta; e Dúris de Samos, pertencente à geração que se seguiu à de Aristóxeno e confesso discípulo de Teofrasto,

${ }^{24}$ Segundo Momigliano (1993 68-73), os peripatéticos estavam interessados em anedotas que ilustram virtudes e vícios para usar nas suas monografias sobre as qualidades individuais, em escritores particulares, em descrever e avaliar escolas filosóficas, e tomaram parte na produção de vários tipos de colecções de anedotas que se tornaram um traço marcante da literatura helenística e latina (entre outros, apophthegmata, gnomai, chreiai, paradeigma), sem que se identificassem necessariamente com biografias.

25 Stuart (1928 129-132 e 135) prefere classificá-lo como membro de um grupo que é o resultado de um processo evolutivo. Momigliano (1993 73-76) acha que foi o primeiro a escrever biografia no Peripatos e que terá sido mesmo o primeiro a tornar as anedotas parte essencial da biografia.

${ }^{26}$ Para demonstrar os excessos do absolutismo, os tiranos são usados como exemplos de vida sumptuosa. Vide Townend 1967 81-82. Stuart (1928 132-134) menciona a obra Tiranos da Sicília como precursora dos Césares de Suetónio.

${ }^{27}$ Papyrus Oxyrbynchus 1176, publicado em 1912.

${ }^{28}$ Viveu em Alexandria por volta de 200. Muito citado por Diógenes Laércio, especialmente para as cenas de morte. Vide Mejer 1978 32-34. 
escreveu Vidas de pintores ${ }^{29}$.

No que diz respeito à estrutura, a escola peripatética tem o mérito de desenvolver a biografia: delineia os seus métodos e os tópicos ${ }^{30}$. Tende a estabelecer-se um esquema mais ou menos fixo: nascimento, juventude e carácter, realizações e morte - momentos acompanhados de reflexão moral. A caracterização da pessoa, já contida no encomion, torna-se mais objectiva: uma biografia formal.

Apesar de mais verídica e realista que o encomium, pois tem em conta os aspectos negativos, faz um retrato físico mais sistemático, refere o vestuário e os gostos pessoais, a biografia peripatética valoriza pouco a cronologia e descura o contexto, polvilha-se de anedotas, de pitoresco e divagações, só para divertir o leitor, e dá crédito a lendas e a material de fontes duvidosas ${ }^{31}$. O fragmento descoberto de Sátiro revela os seus méritos como estilista, mas ausência de espírito crítico. Hermipo, nos fragmentos conservados em Diógenes Laércio, manifesta gosto do escândalo e do sensacionalismo, pela morbidez das cenas de morte e quase completa indiferença em relação ao apuramento da verdade. Multiplicaram-se as recolecções de anedotas, como as relativas às mortes dos homens ilustres. Não se acuse Diógenes Laércio de frivolidade e gosto pelo anedótico, porque foram os próprios filósofos a indicar-lhe o caminho. Mas também é verdade que esta biografia transmite informação relevante sobre a cultura humana e sobre a história literária: inicia a discussão sobre as fontes e influências dos filósofos e homens de letras, incluindo acusações de plágio ${ }^{32}$. Um método caracteristicamente peripatético é inferir elementos biográficos a partir das obras ${ }^{33}$.

Se os peripatéticos são largamente responsáveis pelo desenvolvimento deste género de biografia, a prática não se confinava à escola. Segundo nos diz

${ }^{29}$ Vide Stuart 1928156.

${ }^{30}$ Stuart (1928 185-186) demonstra que, na Vida de Eurípides de Sátiro, já está presente o esquema organizativo que encontramos nas Vidas de Suetónio - a organização cronológica abreviada, no início e na parte final; categorias em vez de cronologia no delineamento da figura ao chegar à idade adulta - , bem como os tópicos essenciais de abordagem; mas, acrescenta Stuart, Sátiro não seria certamente o único a usar tal esquema.

${ }^{31}$ Por exemplo, Diógenes Laércio (3.4 = frg. 24 Müller, FHG II 243), na sua Vida de Platão, cita Dicearco, que coloca o filósofo a competir, como lutador, nos jogos Ístmicos. Aristóxeno não se livra da reputação de amador de escândalos: segundo Porfírio, teria afirmado que Sócrates era licencioso, usurário, pouco erudito, irascível e bígamo (frg. 25-29 Müller, FHG II 280-281); e não era o único a atestar a bigamia (cf. D.L. 2.26). Mas há quem considere Aristóxeno precursor dos métodos realistas modernos e da biografia psicológica. O seu retrato de Sócrates seria o contrapeso realista dos retratos idealizados de Platão e Xenofonte. Vide Stuart 1928 138-143; Hägg 201274.

32 Segundo Diógenes Laércio (3.37), Aristóxeno afirma que Platão copiou inteiramente a República das Contradictiones de Protágoras (= frg. 33 Müller, FHG II 282).

${ }^{33}$ Sátiro deduz muitos dos pormenores sobre Eurípides a partir das tragédias deste autor, como assinala Momigliano 1993 80-81. 
Jerónimo, dos quatro biógrafos gregos considerados precursores do De viris illustribus de Suetónio, Antígono de Caristo, nomeado em segundo lugar, é um académico. Sátiro e Hermipo, considerados embora peripatéticos, trabalham principalmente em Alexandria. Em relação à biografia helenística, as dúvidas são mais que as certezas: é peripatética só em certo sentido, resultava de uma espécie de compromisso. É verdade que implicava pesquisa filológica e era usada pelos filósofos contra escolas rivais, mas o interesse primeiro pela pesquisa dos caracteres de cariz filosófico cedeu aos pormenores anedóticos para satisfazer a curiosidade do leitor ${ }^{34}$. A Vida de Augusto de Nicolau de Damasco é para Momigliano (1993 86) o exemplo mais bem preservado de biografia de um rei segundo a tradição helenística.

Podemos falar de uma biografia propriamente itálica, oriunda de uma tradição independente. As neniae, primitivos lamentos fúnebres, integravam referências às virtudes do defunto; as canções de banquetes, carmina convivalia, segundo nos diz Cícero $^{35}$, existiram até ao tempo de Catão e celebravam as virtudes dos heróis desaparecidos. No atrium romano, as imagines dos antepassados eram acompanhadas dos tituli que as identificavam e enumeravam os cargos civis e militares das pessoas representadas, reunindo os elementos gerais da biografia (antepassados, descendentes, honras e aparência física). O titulus e o elogium constituíam sínteses epigráficas. Estes elementos facultavam o esboço que seria depois desenvolvido pelas laudationes funebres. Estas adquirem forma literária, ganham um elevado estilo de oratória e tornam-se uma verdadeira instituição romana durante a República e o Império.

No século II a.C., vários políticos tentaram escrever autobiografia com intuitos propagandísticos ${ }^{36}$. Multiplicam-se os Commentarii, durante a República e o Império, na senda dos diários de reis e generais helenísticos, como Pirro, ou Arato de Sícion, líder da liga Aqueia, e das inscrições comemorativas de feitos notáveis de aristocratas romanos. Se os Commentarii de Sula eram desadornados, os Commentarii de César alcançaram grande fortuna pela sua qualidade literária, elogiada por Cícero. Augusto, além das Res Gestae, escreve treze livros De vita sua; no que é imitado por Tibério e Cláudio. As Memórias perdidas de Agripina e de Adriano motivaram famosas criações literárias entre nós, de Seomara da Veiga Ferreira e de Marguerite Yourcenar. Os tópicos de

${ }^{34}$ Vide Momigliano 199384.

${ }_{35}$ Tusc. 4.2.3; Brut. 19.75. Vide Stuart 1928 189-220; Momigliano 1990 92-93.

${ }^{36}$ Além de um panfleto de Cornélio Cipião Africano e de algum material biográfico inserido nas Origines de Catão, M. Emílio Escauro e P. Rutílio Rufo são referidos por Tácito (Ag. 1) como cultores do género. Mas o que existia na antiguidade era a noção de vida: a palavra “autobiografia” é invenção moderna. Os Romanos escreviam De vita sua. Vide Bardon 1952 108-115; Badian 1966 13-26; Momigliano 1993 14; Mellor 1999165 ss. 
desenvolvimento do género já figuravam nas laudationes ${ }^{37}$. Foram libertos e clientes os principais autores da antiga história da biografia romana ${ }^{38}$.

A biografia de terceiros parece ter só chegado a Roma no século I a.C. Varrão, Santra, Higino e Cornélio Nepos são considerados por Jerónimo os primeiros cultores da biografia latina. De Santra e Higino o nosso conhecimento é escasso ${ }^{39}$. M. Terêncio Varrão, além de três volumes de autobiografia ( $D e$ vita sua), é autor de uma obra monumental, Imagines ou Hebdomades, talvez a mais antiga obra ilustrada da antiguidade, em que transpõe para a esfera pública da erudição uma tradição romana privada: as imagines das famílias aristocráticas. Ali figuravam gregos e romanos; não só homens de letras, mas também monarcas, políticos, comandantes, $\operatorname{artistas}^{40}$.

Cornélio Nepos, membro do círculo de Pompónio Ático, além de ser autor de três livros de história universal, antecipou Valério Máximo e Plutarco, ao escrever uma colecção de biografias em que comparava gregos e romanos, incluindo mesmo alguns cartagineses e persas (é a primeira colecção de biografias que possuímos da antiguidade). Da colectânea sobrevive, completa, a parte dos generais estrangeiros, além de duas Vidas (Catão Maior e Ático) da parte dos historiadores romanos. Além disso, imitou Varrão, ao publicar uma espécie de álbum de homens ilustres, cujos retratos eram acompanhados de um epigrama. Um traço da erudição helenística é o gosto que Nepos mostra de incluir cartas nas suas biografias. $\mathrm{Na}$ linha da tradição peripatética, escreve para divertir e moralizar ${ }^{41}$. A tradição biográfica erudita aplicada

37 Segundo Lewis (1991 3650-3652), há razão para crer que M. Escauro, nos três livros De vita sua, Sula, nos seus vinte e dois livros sobre a sua carreira, e Augusto, nos De vita sua, seguiram o modelo oratório das laudationes apresentado por Cícero nos discursos forenses.

${ }^{38}$ Cornélio Epicado completou a autobiografia de Sula (Suetónio, Gram. 12); Voltacílio Pitolau celebrou as façanhas de Pompeio Magno e do pai deste, Pompeio Estrabão (Suetónio, Rhet. 27); Tirão foi liberto e biógrafo de Cícero; Júlio Márato escreveu registos da vida de Augusto (cf. Suetónio, Aug. 79.2; 94.3). Vide Bardon 1952, 270-276; Lewis 1966, 271-273; Baldwin 1983, 66-68.

${ }^{39}$ De Santra chegou-nos o juízo negativo de Marcial (11.2.7) e de Quintiliano (11.2.46) sobre a aspereza do discurso. Terá provavelmente escrito um De viris illustribus, ou simplesmente De poetis, ou ambos (cf. Suetónio, Ter. 4, e Gram. 14.4). Quanto a Higino, Suetónio menciona-o de passagem, em De grammaticis 20, sem citar os seus escritos, mas Aulo Gélio (1.14.1; 1.21.2; 16.6.14) louva o seu trabalho de grammaticus e diz que ele escreveu seis volumes de De vita rebusque illustrium virorum. Vide Baldwin 1983, 83-84; Bardon 1952, 297-298 e 328; Kaster 1995, 205-214.

40 Composta por quinze livros, continha setecentos retratos de homens célebres, acompanhados, para cada caso, de um epigrama de louvor e resumo da vida e obra. O texto poético seria completado com discussões eruditas em prosa, como notas de rodapé. Aulo Gélio, 3.11, refere discussões sobre a cronologia de Homero e Hesíodo. Vide Baldwin 198379 e 83; Jenkinson 1967 4-5; Momigliano1993, 96-97.

${ }^{41}$ Mistura os capítulos relativos à vida privada com os da vida pública e os que seguem a ordem cronológica com os de carácter sistemático. Revela consciência da distinção entre história e biografia: Pel. 1.1. Vide Tuplin 1979 124-142; Momigliano 1993, 99 n. 40; Giua 1990, 536-537. 
à história de grandes políticos romanos continua, em língua grega, com Nicolau de Damasco ${ }^{42}$ e Plutarco e, em latim, com Plínio-o-Velho, Titínio Capitão e Suetónio ${ }^{43}$. Com este último a biografia política consolidou-se nos imperadores; enquanto o Agricola de Tácito continua a tradição encomiástica da laudatio, como, já antes, as biografias perdidas de Trásea Peto, da autoria de Aruleno Rústico, e de Helvídio Prisco, da autoria de Herénio Senecião.

Em suma, a biografia aparece em circunstâncias de admiração por determinado personagem carismático (por exemplo Sócrates); o objectivo pode ser panegírico, didáctico, apologético, propagandístico, polémico (no caso do conflito entre escolas filosóficas) ou meramente lúdico. É um género flexível, facilmente adaptável, o que torna difícil a sua definição; apresenta geralmente o biografado do nascimento à morte; é frequentemente usado na esfera ritual e religiosa ${ }^{44}$. A busca dos pormenores anedóticos e curiosidades coloca a biografia no âmbito do que mais tarde se chamou antiquária, uma designação moderna para uma realidade antiga ${ }^{45}$ que traduz o interesse por minudências do passado, por eventos fora do vulgar, monstruosidades, histórias locais, listas de magistrados, nomes próprios, leis, costumes, em suma, a erudição como um fim em si ${ }^{46}$.

$\mathrm{Na}$ tradição da historiografia curiosa da primeira escola aristotélica coloca Gigante (1976 xx) Diógenes Laércio. As máximas constituem rubricas

42 Nicolau de Damasco, contemporâneo de Augusto, é autor de uma história universal, biografia e autobiografia: sobrevivem fragmentos da sua biografia de Augusto e da sua autobiografia, que constituem os mais antigos exemplos da biografia helenística a seguir a Sátiro. Vide Baldwin 1983, 85-87; Momigliano 1993 9; 112; 118.

${ }^{43}$ Segundo a tese de Leo (1901), a biografia, no período helenístico e romano, apresentava, em geral, dois modelos distintos: as Vidas dos políticos e generais estavam normalmente organizadas de forma cronológica, enquanto as Vidas dos filósofos, artistas e poetas se apresentavam organizadas de forma sistemática. Suetónio, ao organizar de forma sistemática as Vidas dos Césares, transfere para homens de acção um tipo de biografia alexandrina, que era usada normalmente em escritores e artistas. Mas, segundo Stuart (1928 186-187), a descoberta do papiro que continha a Vida de Eurípides de Sátiro veio provar que este esquema biográfico já existia antes de aparecerem as biografias eruditas alexandrinas, pelo que apresentou as biografias alexandrinas como seguidoras de uma estrutura herdada dos peripatéticos. Momigliano (1993, 87-88; 105 ss) contesta a base da tese de Leo e conclui que não existiam apenas dois, mas variados modelos de biografias. Vide Wallace-Hadrill 198470.

${ }^{44}$ Como sintetisa Grau e Guijarro 2009 31-32 e 37.

${ }^{45} \mathrm{Na}$ época helenística e romana, o criticus, philologus, polyistor, grammmaticus, doctus, litteratus ou eruditus. Uma designação apropriada é archaeologus e encontra-se em Platão, $H p$. Ma. 285d, segundo o qual arqueologia inclui, entre outros assuntos, genealogias de heróis e tradições acerca da fundação de cidades. Vide Wallace-Hadrill 1984 126-129.

${ }^{46}$ Banidos pela pesquisa histórica tradicional, aqueles temas foram objecto de estudo dos sofistas: Hípias escreve sobre nomes de nações e Crítias transcreve constituições de várias cidades. A oposição entre archaeologia e historia não se manteve. Arqueologia passa a designar, na época helenística e romana, um trabalho de história arcaica ou uma história desenvolvida desde as origens: assim em Dionísio de Halicarnasso e em Flávio Josefo. Vide Momigliano 1990 58-60. 
bastante atractivas. O anedotário é essencial para a descrição do carácter. Uma vez que inserido nesta tradição e enquanto recolector de elementos biográficos e doxográficos não se lhe pode pedir que seja original. As secções biográficas (incluindo apotegmas e anedotas) ocupam o maior espaço e muitas biografias não têm doxografia. As autoridades citadas são sobre a vida e escritos dos filósofos e não tanto sobre os seus ensinamentos. Quando quer dizer alguma coisa dos sistemas filosóficos, Diógenes Laércio recorre a outras fontes, diferentes das que usa para os aspectos propriamente biográficos. E não está interessado, como vimos, nas teorias individuais (com poucas excepções), mas nos sistemas maiores. No que respeita à biografia propriamente filosófica, há o contributo de quatro grandes grupos de obras: sucessões de filósofos (diadochaì) que acentuam a relação mestre-discípulo e contêm elementos comuns da biografia (como o lugar de origem, relações familiares e com filósofos, dados biográficos, anedotas e apotegmas) e cuja informação filosófica não ocupava a maior parte; exposição de sistemas filosóficos de determinada escola ou escolas (Peri haireseon); obras propriamente doxográficas (areskonta, dogmata, placita); biografias propriamente ditas de filósofos singularizados $(\text { Bioi })^{47}$. A parte doxográfica onde Diógenes parece ter mais cuidado em referir um largo número de autoridades é na doxografia estóica, introduzida na Vida de Zenão $(7.38-159)^{48}$.

Quanto aos tópicos característicos da biografia ${ }^{49}$, presentes no livro VII, evidencia-se, no que respeita à juventude e educação, a conversão ou iniciação através da sedução de um livro: Zenão é aconselhado por um oráculo a ler livros antigos, a partir dos quais se inclinou para a filosofia; ou a leitura dos Memoráveis de Xenofonte levou-o a pedir ao livreiro em Atenas que lhe mostrasse um sábio - e o livreiro apontou-lhe Crates (7.2-3). Outros falam de uma formação filosófica desde a infância: o pai comerciante levava-lhe de Atenas livros dos socráticos (7.31). Mas está presente a noção de uma tyche providencial: um naufrágio que lhe aponta o caminho da filosofia (7.5). Sinais que já indicavam um futuro auspicioso e os acasos que determinaram uma vida fazem as delícias dos biógrafos.

Outro elemento bastante presente são as grandes mudanças, porque reveladoras do carácter: nas vidas dos imperadores, as mudanças para o bem

\footnotetext{
${ }^{47}$ Vide Mejer 1978 61-93.

${ }^{48}$ Segundo Von Arnim (In stoicorum veterum fragmenta I, Leipzig 1905: apud Mejer 1978 5), esta doxografia é constituída por três elementos: 1) levantamento geral da filosofia estóica numa espécie de compêndio (compendium exile); 2) uma série de excertos entremeados de afirmações de estóicos (indices eclogarum); 3) um excerto da "Sinopse (epidrome) dos filósofos" de Díocles de Magnésia, acrescentado por Diógenes (como este diz em 7.48), para uma mais completa explanação da lógica estóica (7.49-82). O mais provável é que toda a doxografia estóica tenha sido importada de outra fonte, que não as habituais, segundo pensa Mejer 1978 1-7.

${ }^{49}$ Para o elenco dos elementos biográficos, vide Grau i Guijarro 2009205 ss.
} 
ou, a maior parte das vezes, para o mal; nas futuras vidas dos santos a conversão; nos filósofos a troca de uma escola por outra: Crisipo abandona o Pórtico e passa para a Academia (7.183); Aríston deserta de Zenão, quando este estava doente (7.162) - tanto num caso como no outro Diógenes Laércio dedica um epigrama a censurar a atitude $(7.184 ; 7.164)$. Dionísio deserta de Zenão e passa para os cirenaicos (7.167). A conversão pode passar pela rejeição do passado, através da queima de livros, por exemplo, ou abandono de todos os bens para mudar radicalmente de vida. Crisipo deixa a corrida de fundo e converte-se à filosofia depois de ouvir Zenão ou Cleantes (7.179), ou porque os seus bens foram confiscados (7.181). A mudança é por vezes reforçada pela atribuição de um nome, muitas vezes uma alcunha burlesca que caracteriza o biografado: Aríston é o Calvo ou a Sereia (7.160), Dionísio, o Apóstata (7.166); Cleantes o Phreantles, isto é 'Tirador de água do poço', jogando com o nome e uma actividade paralela, enquanto se dedicava à filosofia (7.168); mas também Hércules, pela resistência anímica (1.170).

Caracteristicamente biográficos são os retratos físicos. Para os antigos o aspecto físico espelhava o carácter, segundo as teorias fisiognomónicas. Cleantes repetiria um dito de Zenão: de que o ethos se compreende através do eidos (1.173). Mas as descrições são estereótipos de filósofos. A par do ideal de beleza divina, surge frequentemente o lugar-comum dos barbudos, como é o caso de Zenão (7.26). Também marcantes são os vitia corporis (7.1).

Entre as qualidades intelectuais, a sabedoria é a principal, acompanhada da versatilidade. Zenão é apreciado pela ânsia de investigar (7.1); e uma extraordinária diligência é creditada a Crisipo (7.180). Mas uma tradição hostil pode denegrir, como é o caso de Cleantes, acusado de ser lento e pouco dotado (7.170). Outro traço presente nas biografias tanto de políticos como de homens das letras era a eloquência: Aríston parecia ter nascido para falar e seduzir as multidões (7.161). Ligado muitas vezes a este aspecto aparece a produção literária. Os escritos de Zenão (7.4) são elogiados por Diógenes como os melhores entre os estóicos (7.33). Destaca-se, pela negativa, a prolixidade de Crisipo: o confronto com Epicuro favorece o último (7.180-181). Crisipo é ainda criticado por fazer um pastiche de citações, frente à originalidade de daquele autor. Além disso, manifesta arrogância na forma como publica os seus escritos (7.185). O reconhecimento público e a fama acompanham Zenão (7.6; 10-12), Aríston (7.161), Cleantes (7.169). Crisipo é admirado pela dialéctica (7.180).

Outra rubrica é a diária incluindo a alimentação, com implícito elogio da frugalidade. O vício contrário seria a luxuria de que a gula é uma das manifestações. Zenão manifesta a sua ascese ao comer pequenos pães e mel (7.3) e alimentos não cozinhados (7.16), em contraste com a versão hostil de que se mostrava alarve à mesa (7.19), e ao envergar a mesma roupa de 
Verão e de Inverno (7.26-27), o que contribui também para uma imagem de parcimónia. O resultado é a resistência a doenças (7.27-28). E, no extremo, um autodomínio tal, que era capaz de induzir a morte parando simplesmente de respirar.

O topos da vida sexual e matrimónios pode ser usado para aferir da coerência entre a vida do filósofo e a doutrina. Zenão defendia na sua República que o sábio devia ter mulher e gerar filhos (7.121). Ele próprio tinha comércio carnal com rapazes e com uma ou duas cortesãs, para não parecer misógino (7.13), o que faz passar uma imagem de moderação. Já Herilo tinha demasiados amantes na juventude (7.166). Dionísio, convertido aos Cirenaicos, passou a ser frequentador de bordéis (7.167).

As colecções de 'belas palavras' abundam, para mais, sendo os filósofos por excelência produtores de máximas, as famosas chreiai (ditos anedóticos concisos apresentados em contexto narrativo). E é uma forma de Diógnes unir biografia e doxografia ${ }^{50}$. Se, como sugere Plutarco, um bon mot espelha o carácter, também pode traduzir o pensamento filosófico. Por exemplo, de Crisipo acumulam-se sucessivamente de forma narrativa uma série de sofismas sem qualquer comentário (7.186-187). Frequentemente as máximas são substituídas por citações trágicas e épicas (7.172; 7.179; 7.183; 7.182), de Hesíodo (7.25) ou até da comédia (7.163).

Uma das rubricas mais importantes da biografia é seguramente o relato da morte; tão importante que a de homens ilustres se tornara um género independente, e concretamente a morte de filósofos (Hermipo terá escrito algo do género). Apareceram relatos laudatórios sobre as vítimas de Nero e dos Flávios em que se destacavam vítimas da oposição estóica ${ }^{51}$. Na morte se revela a plenitude do ethos, costuma dizer-se. $\mathrm{O}$ trespasse tende a ser visto na biografia como prémio ou castigo da vida. Há por isso uma tendência para relacionar o género de morte com a forma como se conduziu a vida. No caso dos filósofos, a morte pode ilustrar ou desmentir algum aspecto da filosofia do biografado, com efeitos sobre a avaliação do carácter. Além disso, estava arreigada no imaginário grego antigo a ideia de que as mortes dos poetas e filósofos seriam terríveis e absurdas ${ }^{52}$. Se os heróis históricos morrem jovens, normalmente os filósofos morrem em idade muito avançada, como convém a um sábio - e sageza e

${ }^{50}$ Vide Grau i Guijarro 2009375.

${ }^{51}$ Fânio escreve sobre occisi aut relegati a Neroni: cf. Plínio, Ep. 5.5.2. Titínio Capitão, ab epistulis, que fez carreira nos principados de Domiciano, Nerva e Trajano, continuou a ligação entre biografia e imagines, pois tinha em casa retratos de Bruto, Cássio e Catão, que viriam acompanhados de laudationes em verso. Escreveu relatos da morte de vários amigos: exitus illustrium virorum (um género em voga): Cf. Plínio, Ep. 8.12.5. O próprio Plínio escreve de ultione Helvidi Prisci (o jovem) (Ep. 9.13; 5.8).

${ }^{52}$ Vide Grau i Guijarro 2009429. 
senectude andavam a par. Através da morte se pode associar um filósofo a outro, como o caso de Cleantes, de quem se diz que morreu com a mesma idade que Zenão, seu mestre e antecessor (7.176). De qualquer modo, a biografia gosta de explorar estas coincidências (Suetónio contém inúmeras).

Frequentemente a morte é apresentada como ridícula: a de Aríston provocada por sol na cabeça, porque era calvo, motiva o chiste de Diógenes num epigrama (7.164) - uma interferência do topos cómico sobre a calvície, característica física que a biografia assinala amiúde. A morte de Zenão acontece quando cai à porta da escola: parte um dedo, pronuncia um verso de Niobe de Timeu de Mileto (7.28) e fina-se. Segundo alguns estudiosos, como para os estóicos o dedo é símbolo de conhecimento, a fractura é uma mensagem da própria terra (a cujo apelo Zenão responde) sobre o fim da carreira filosófica,em resultado de uma espécie de omen, paralelo ao oráculo que o levara a enveredar pela filosofia. Esta morte aparenta, além disso, um suicídio por suspensão da respiração (7.28); ou, segundo outra versão, por recusa da comida (7.31). A morte por auto-asfixia reforça a noção de autarcheia e eleutheria do sábio. O suicídio por inanição é a escolha também de Dionísio (7.167) e Cleantes (7.176). Este teria posto fim à vida na sequência de um tratamento a uma inflamação nas gengivas ${ }^{53}$. Mais burlesca é a morte de Crisipo, ocorrida depois de ele beber vinho puro e ao fim de cinco dias de agonia (7.184); ou, segundo outra versão, na sequência de uma risada, depois de verificar que um burro tinha comido os seus figos: de acordo com o seu sentido de humor, manda dar também vinho puro ao animal (1.785). Diógenes dedica-lhe um epigrama duro sobre o facto: o topos de beber vinho puro era frequente no epigrama, como mostra por exemplo Marcial.

Outra rubrica é a fama post mortem. Zenão recebe grandes honras fúnebres de Atenas ao ponto de ser enterrado a expensas públicas no Ceramico, onde jazem os heróis da pátria (7.11-12; 29). A apoteose (atribuída aos heróis) é celebrada num epigrama (7.69), na linha dos novos cultos heróicos a personagens históricos. No decreto de Atenas para honrar Zenão, a ideia de que educar os jovens era sinal de status do filósofo na pólis e prova da sua estima era mais um elemento biográfico, sem confirmação epigráfica para aquela época. Outro motivo do discurso é de que Zenão viveu de acordo com os seus ensinamentos - mais um elemento central na biografia para caracterizar um bom filósofo, com base num documento que até pode ser ficcionado ${ }^{54}$. Forjar documentos

${ }^{53}$ Já Filodemo (26-27) fala de um tumor maligno e de uma convocatória aos discípulos, segundo o modelo socrático, para explicar o motivo do suicídio.

${ }^{54}$ Há quem afirme que se possa tratar de um documento forjado ou distorcido, talvez por Apolodoro de Tiro, a fonte de Laércio, com intenção apologética contra os detratores de Zenão, uma vez que as honras da cidade são concedidas em função dos valores da pólis e não em nome de valores filosóficos criados por um indivíduo. Vide Haake 2004 470-483. 
não era nada de extraordinário na época: há outros exemplos na biografia.

O tema da sucessão é recorrente nas biografias de filósofos e os discípulos constituem também uma rubrica. A Vida de Esfero (7.177-178), não será uma vida à parte, uma vez que Laércio (7.37) diz que vai tratar este filósofo na Vida de Cleantes. Assim, também as Vidas de Aríston, Herilo e Dionísio devem ser consideradas parte da Vida de Zenão ${ }^{55}$.

Em suma, por estes exemplos vemos que Diógenes se integra perfeitamente na tradição biográfica: o que o autor trata são, antes de mais, Vidas - este é o género - filósofos é um dos assuntos possíveis das Vidas, como já fizeram os seus predecessores. São esclarecimentos que, por si, anulam as críticas contra Diógenes de que lhe falta o rigor na filosofia. Vê-se claramente que está preocupado em descrever a Vida no seu todo, reunindo informações diversas e por vezes discordantes, com origens diversas, mas que ajudam a esclarecer o carácter, além daquela preocupação erudita de procurar ser completo. Escreve não para especialistas, mas para um público geral, e por isso não exclui o pormenor picante que serve de engodo para o leitor comum. O seu objectivo é a erudição e a informação ética.

${ }^{55}$ Vide Mejer 197816 n. 31. 


\section{BibLiogRAFIA}

J.-M. André - A. Hus (1974), Histoire à Rome. Historiens et biographes dans la littérature latine. Paris, P.U.F.

M. M. Austin (1990), “Greek Tyrants and the Persians, 546-479 B. C.”, CQ 40 289-306.

E. Badian (1966), “The early historians” in T. A. Dorey, ed. Latin historians. London, Routledge \& Kegan Paul 1-38.

B. Baldwin (1983), Suetonius. Amsterdam, Hakkert.

H. Bardon (1952), La littérature latine inconnue. Paris, Klincksieck.

J. L. Brandão (2009), Máscaras dos Césares. Teatro e moralidade nas Vidas suetonianas. Coimbra, Classica Digitalia/CECH.

A. Dihle (1956), Studien zur Griechischen Biographie. Göttingen, Vandenhoeck \& Ruprecht.

M. A. Giua (1990), "Aspetti della biografia latina del primo impero”, RSI 12 535-559.

S. Grau i Guijarro (2009), La imatge del filòsof i de l'activitat filosòfica a la Grècia antiga: anàlisi dels tòpics biogràfics presents a les Vides i doctrines dels filòsofs més illustres de Dioggenes Laerci. Barcelona, PPU.

H. Haake (2004), "Documentary evidence, literary forgery, or manipulation of historical documents? Diogenes Laertius and an Athenian honorary decree for Zeno of Citium", CQ 54 470-483.

T. Hägg (2012), The art of biography in antiquity. Cambridge, University Press.

F. Jacoby (1947), "Some Remarks on Ion of Chios”, CQ 41 1-17.

E. Jenkinson (1967), "Nepos. An introduction to Latin biography" in T. A. Dorey, ed. Latin biography. London, Routledge \& Kegan Paul 1-15.

R. A. Kaster (1995), C. Suetonius Tranquillus. De grammaticis et rhetoribus. Edição, trad., intr. e notas. Oxford, Clarendon Press.

F. Leo (1901), Die griechisch-römische Biographie nach ibrer litterarischen Form. Leipzig, Teubner.

R. G. Lewis (1966), “Pompeius' freedman biographer”, CR 16 271-273. (1991), "Suetonius' Caesares and their literary antecedents" in W. Haase, ed. $A N R W$, II 33.5. Berlin/Nova Iorque, Walter de Gruyter 3623-3674. 
J. Mejer (1978) Diogenes Laertius and his Hellenistic Background. Wiesbaden, Steiner.

R. Mellor (1999), The Roman Historians. London, Routledge.

A. Momigliano (1990), The classical foundations of the modern historiography. Berkeley, University of California Press.

(1993), The development of Greek biography. Cambridge MA/London, Harvard University Press.

W. Steidle (21963), Sueton und die antike Biographie. München, Beck. [1 $1^{\mathrm{a}} \mathrm{ed}$. 1951]

D. R. Stuart (1928), Epochs of Greek and Roman biography. New York, Biblo and Tannen (repr. 1967).

G. B. Townend (1967), "Suetonius and his influence" in T. A. Dorey, ed. Latin biography. London, Routledge \& Kegan Paul 79-111.

C. Tuplin (2000), "Nepos and the origins of political biography" in C. Deroux, ed. Studies in Latin literature and Roman history, X. Bruxelles, Latomus 124-161.

B. L. Ullman (1942), "History and tragedy", TAPhA 73 25-53.

A. Wallace-Hadrill (1984), Suetonius. The scholar and his Caesars. New Haven, Yale University Press. 